\title{
Organic trace minerals and calcium levels in broilers' diets to 21 days old
}

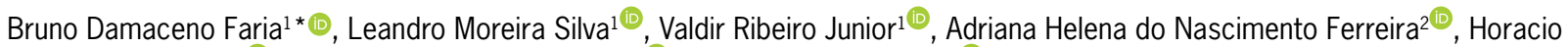 \\ Santiago Rostagno ${ }^{1 \mathbb{0}}$, Luiz Fernando Teixeira Albino ${ }^{10}$, Melissa Izabel Hannas ${ }^{10}$
}

\author{
${ }^{1}$ Universidade Federal de Viçosa - Depto. de Zootecnia, Av. \\ Peter Henry Rolfs, s/n - 36570-900 - Viçosa, MG - Brasil. \\ ${ }^{2}$ Alltech do Brasil, Av. Paranavaí, 2468 - 87070-130 - \\ Maringá, PR - Brasil. \\ *Corresponding author <brunodfzoo@gmail.com>
}

Edited by: Antonio Faciola

Received March 09, 2018

Accepted August 01, 2018
ABSTRACT: This study was undertaken to evaluate the effects of dietary calcium levels and supplementation with organic trace minerals selenium, copper, iron, zinc and manganese on performance, tissue deposition and litter mineral concentration. A total of 2,496 one-day-old male Cobb 500 broilers were randomly assigned to a $3 \times 4$ factorial experimental design with three levels of dietary $\mathrm{Ca}$ [8, 10 and $12 \mathrm{~g} \mathrm{~kg}^{-1}$, while maintaining the same Ca:nPP (non-phytate phosphorus) ratio (2:1)] and four levels of micromineral supplementation $(0.62,0.72,0.82$ and $0.92 \mathrm{~g} \mathrm{~kg}^{-1}$ ). There was a total of 12 treatments, with eight replicates of 26 birds per pen. Micromineral supplementation (MS) was achieved by adding different levels of the product Bioplex TR Se ${ }^{\circledR}$ and Ca supplementation was achieved by adding increasing levels of limestone and dicalcium phosphate. An interaction between $\mathrm{Ca}$ and MS levels was observed $(p<0.05)$ for the parameters of performance, liver Cu concentration, breast $\mathrm{Se}$ and $\mathrm{Cu}$ concentrations and litter Se, Mn and Zn concentrations. No interactions were observed ( $p>0.05)$ for $\mathrm{Ca}, \mathrm{P}$ or ash concentrations in the tibia, which were influenced only by dietary $\mathrm{Ca}$ levels $(p<0.05)$. The Ca level of $10 \mathrm{~g} \mathrm{~kg}^{-1}$ promoted higher $\mathrm{Ca}$ and $\mathrm{P}$ concentration in the tibia and lower micromineral excretion in the litter. The combination of MS level of $0.82 \mathrm{~g} \mathrm{~kg}^{-1}$ with Ca level of $10 \mathrm{~g} \mathrm{~kg}^{-1}$ led to the best BWG response. The supplementation conditions that led to higher micromineral levels in the liver and breast varied for each mineral.

Keywords: chicken, micromineral, tibia, breast muscle

\section{Introduction}

Inadequate mineral supplementation during the growth phase of birds results in an imbalance in mineral homeostasis and improper development of bones, i.e., abnormal bone calcification. However, excess calcium (Ca) may act as an antagonist, making it difficult to absorb trace minerals such as iron $(\mathrm{Fe})$, copper $(\mathrm{Cu})$, zinc $(\mathrm{Zn})$ and other minerals such as magnesium $(\mathrm{Mg})$, sodium (Na) and potassium (K) (Smith and Kabaija, 1985; Waldroup, 1996). High Ca levels in broiler chicken feed increase the need for phosphorus $(\mathrm{P})$ because $\mathrm{Ca}$ interferes with phosphorus absorption. Ca and $\mathrm{P}$ form complexes in the intestine, making $\mathrm{P}$ less available hindering the absorption of phytin phosphorus by the bird (Wise, 1983).

Trace minerals such as selenium (Se), $\mathrm{Cu}, \mathrm{Fe}$, manganese $(\mathrm{Mn})$ and $\mathrm{Zn}$ are essential to chicken development because they are active in several metabolic pathways. These minerals are involved in physiological functions that are essential to the maintenance of life, including reproduction, growth, immune system function, bone formation and energy metabolism (Dieck et al., 2003; Bao et al., 2007; Dibner et al., 2007). They are usually supplemented in the form of inorganic salts, such as sulphates, oxides and carbonates, to ensure healthy development and greater productivity. However, these inorganic forms are thought to interact with other minerals, such as Ca. This negative effect can be minimized by supplementing these minerals in organic form.

The aim of the present study was to evaluate the effects of dietary Ca levels (while maintaining the same
$\mathrm{Ca}: \mathrm{P}$ ratio) and different supplementation levels of the organic trace minerals $\mathrm{Se}, \mathrm{Cu}, \mathrm{Fe}, \mathrm{Zn}$ and $\mathrm{Mn}$ on the performance, tissue deposition and mineral excretion in the litter.

\section{Materials and Methods}

The study was approved by the Ethics Committee for the Use of Production Animals (CEUAP) of the Universidade Federal de Viçosa (UFV; Minas Gerais, Brazil), with number 100/2014.

The experiment was conducted in Viçosa $\left(20^{\circ} 45^{\prime} 14^{\prime \prime} \mathrm{S}, 42^{\circ} 52^{\prime} 53^{\prime \prime} \mathrm{W}\right.$ and $648.74 \mathrm{~m}$ of altitude), in the state of Minas Gerais, Brazil.

A total of 2,496 one-day-old male Cobb 500 broiler chicks with a mean initial weight of $44 \mathrm{~g}$ were housed up to 21 days of age in 96 pens (experimental units) with $3 \mathrm{~m}^{2}$ each, which were lined with wood shavings and located within a masonry shed.

The experimental design was fully randomized, with 12 treatments (Table 1 ) in a $3 \times 4$ factorial design that consisted of three levels of dietary $\mathrm{Ca}[8,10$ and 12 $\mathrm{g} \mathrm{kg}^{-1}$, with a constant Ca:nPP (non-phytate phosphorus) ratio of 2:1] and four levels of micromineral supplementation $\left(0.62,0.72,0.82\right.$ and $\left.0.92 \mathrm{~g} \mathrm{~kg}^{-1}\right)$. Each treatment consisted of eight replicates of 26 birds.

The corn-soybean meal basal diets (Table 2) were formulated so as to be adequate in all nutrients according to Rostagno et al. (2011) with the exception of the microminerals ( $\mathrm{Mn}, \mathrm{Zn}, \mathrm{Fe}, \mathrm{Cu}$ and $\mathrm{Se}$ ) and $\mathrm{Ca}$ levels, which were added based on respective treatments. The diets were supplemented with a Escherichia coli - derived 
Table 1 - Experimental treatments and organic trace minerals levels ${ }^{1}$.

\begin{tabular}{|c|c|c|c|c|c|c|c|c|}
\hline Treatment & $\mathrm{Ca}$ & $\mathrm{nPP}$ & MS & $\mathrm{Mn}$ & $\mathrm{Zn}$ & $\mathrm{Fe}$ & $\mathrm{Cu}$ & $\mathrm{Se}$ \\
\hline & & $\mathrm{kg}^{-1}$ & & & & $\mathrm{ppm}$. & & \\
\hline T1 & \multirow{4}{*}{8} & \multirow{4}{*}{4} & 0.62 & 31 & 24.8 & 18.6 & 3.72 & 0.112 \\
\hline T2 & & & 0.72 & 36 & 28.8 & 21.6 & 4.32 & 0.130 \\
\hline T3 & & & 0.82 & 41 & 32.8 & 24.6 & 4.92 & 0.148 \\
\hline T4 & & & 0.92 & 46 & 36.8 & 27.6 & 5.52 & 0.166 \\
\hline $\mathrm{T5}$ & \multirow{4}{*}{10} & \multirow{4}{*}{5} & 0.62 & 31 & 24.8 & 18.6 & 3.72 & 0.112 \\
\hline T6 & & & 0.72 & 36 & 28.8 & 21.6 & 4.32 & 0.130 \\
\hline T7 & & & 0.82 & 41 & 32.8 & 24.6 & 4.92 & 0.148 \\
\hline T8 & & & 0.92 & 46 & 36.8 & 27.6 & 5.52 & 0.166 \\
\hline T9 & \multirow{4}{*}{12} & \multirow{4}{*}{6} & 0.62 & 31 & 24.8 & 18.6 & 3.72 & 0.112 \\
\hline $\mathrm{T} 10$ & & & 0.72 & 36 & 28.8 & 21.6 & 4.32 & 0.130 \\
\hline $\mathrm{T} 11$ & & & 0.82 & 41 & 32.8 & 24.6 & 4.92 & 0.148 \\
\hline T12 & & & 0.92 & 46 & 36.8 & 27.6 & 5.52 & 0.166 \\
\hline
\end{tabular}

${ }^{1}$ The minerals were supplied by the micromineral supplementation (MS), which contained $50 \mathrm{~g} \mathrm{~kg}^{-1}$ manganese (Mn), $40 \mathrm{~g} \mathrm{~kg}^{-1}$ zinc (Zn), $30 \mathrm{~g} \mathrm{~kg}^{-1}$, iron ( $\mathrm{Fe}$ ), $6 \mathrm{~g} \mathrm{~kg}^{-1}$ copper (Cu), $180 \mathrm{mg} \mathrm{kg}^{-1}$ selenium (Se) and $2 \mathrm{~g} \mathrm{~kg}^{-1}$ iodine (I). Ca supplementation was achieved by adding increasing levels of limestone (377 $\mathrm{g}$ of Ca per $\mathrm{kg}$ of limestone) and dicalcium phosphate ( $245 \mathrm{~g}$ of Ca and $185 \mathrm{~g}$ of $\mathrm{P}$ available per $\mathrm{kg}$ of dicalcium phosphate). phytase $15,000 \mathrm{FTU} \mathrm{g}^{-1}$ of phytase, providing 1000 FTU per $\mathrm{kg}$ of diet) to simulate a commom comercial diet.

Trace mineral supplementation was achieved by adding different levels of a commercial micromineral supplement (MS), which contains $50 \mathrm{~g}$ Mn, $40 \mathrm{~g} \mathrm{Zn}, 30 \mathrm{~g}$ $\mathrm{Fe}$ and $6 \mathrm{~g} \mathrm{Cu}$ (as proteinates), $180 \mathrm{mg}$ Se (derived from yeast enrichment) and $2 \mathrm{~g}$ I (as inorganic source) per kilogram of the product.

Ca supplementation was performed by adding increasing levels of limestone (377 $\mathrm{g}$ of Ca per kg of limestone). The Ca:nPP ratio was maintained in the different treatments by adding different levels of dicalcium phosphate $\left(\mathrm{CaHPO}_{4}\right.$. with $245 \mathrm{~g}$ of $\mathrm{Ca}$ and $185 \mathrm{~g}$ of $\mathrm{P}$ available per $\mathrm{kg}$ of dicalcium phosphate), limestone and an inert material (washed sand).

Each experimental unit was equipped with a nipple and feeder to provide water and feed ad libitum. The feed was given according to the consumption of the animals in each experimental unit. The birds and leftover feed were weighed at the beginning of the experiment

Table 2 - Ingredients and nutrient composition of the basal diets.

\begin{tabular}{|c|c|c|c|}
\hline & \multicolumn{3}{|c|}{$\mathrm{Ca}\left(\mathrm{g} \mathrm{kg}^{-1}\right)$} \\
\hline Ingredient & 8 & 10 & 12 \\
\hline Corn & 537.40 & 537.40 & 537.40 \\
\hline Soybean meal 46 & 379.10 & 379.10 & 379.10 \\
\hline Soy oil & 35.00 & 35.00 & 35.00 \\
\hline Washed sand* & $15.93 / 15.83 / 15.73 / 15.63^{2}$ & $8.72 / 8.62 / 8.52 / 8.42^{3}$ & $1.53 / 1.43 / 1.33 / 1.23^{4}$ \\
\hline Dicalcium phosphate & 9.97 & 15.37 & 20.78 \\
\hline Limestone & 9.25 & 11.06 & 12.84 \\
\hline $\mathrm{NaCl}$ & 4.80 & 4.80 & 4.80 \\
\hline DL-methionine & 2.85 & 2.85 & 2.85 \\
\hline L-lysine $\mathrm{HCl}$ & 1.57 & 1.57 & 1.57 \\
\hline L-threonine & 0.41 & 0.41 & 0.41 \\
\hline Choline chloride, $60 \%$ & 1.00 & 1.00 & 1.00 \\
\hline Vitamin supplement ${ }^{1}$ & 1.25 & 1.25 & 1.25 \\
\hline Mineral supplement* & $0.62 / 0.72 / 0.82 / 0.92^{2}$ & $0.62 / 0.72 / 0.82 / 0.92^{3}$ & $0.62 / 0.72 / 0.82 / 0.92^{4}$ \\
\hline Anticoccidial salinomycin $12 \%$ & 0.55 & 0.55 & 0.55 \\
\hline Antioxidant $^{5}$ & 0.10 & 0.10 & 0.10 \\
\hline Phytase $^{6}$ & 0.20 & 0.20 & 0.20 \\
\hline \multicolumn{4}{|c|}{ Calculated nutrient content } \\
\hline Crude protein & 217.13 & 217.13 & 217.13 \\
\hline ME $\left(\mathrm{kcal} \mathrm{kg}^{-1}\right)^{7}$ & 3,000 & 3,000 & 3,000 \\
\hline Calcium & 8.0 & 10.0 & 12.0 \\
\hline Non-phytate phosphorus & 4 & 5 & 6 \\
\hline $\mathrm{Na}$ & 2.09 & 2.09 & 2.09 \\
\hline Dig. lysine & 12.00 & 12.00 & 12.00 \\
\hline Dig. methionine & 5.73 & 5.73 & 5.73 \\
\hline Dig. methionine + cysteine & 8.68 & 8.68 & 8.68 \\
\hline Dig. threonine & 7.80 & 7.80 & 7.80 \\
\hline Dig. tryptophan & 2.47 & 2.47 & 2.47 \\
\hline Dig. arginine & 13.86 & 13.86 & 13.86 \\
\hline Dig. valine & 9.24 & 9.24 & 9.24 \\
\hline
\end{tabular}


and at 21 days of age to determine body weight gain (BWG, kg), feed intake (FI, kg) and feed-to-gain ratio $\left(\mathrm{F}: \mathrm{G}, \mathrm{kg} \mathrm{kg}^{-1}\right)$. The number of birds dying throughout the experimental period was quantified to calculate viability. F:G was determined considering the correction of feed intake by birds alive in each unit. For this each feeder unit was weighed after a dead bird was detected. Temperature was measured daily. In the first week, the mean minimum and maximum temperatures were $25^{\circ} \mathrm{C}$ and $32{ }^{\circ} \mathrm{C}$, respectively. These temperatures were $21{ }^{\circ} \mathrm{C}$ and $31{ }^{\circ} \mathrm{C}$ from day 8 to 21 .

At 21 days of age, one bird per pen (eight birds per treatment) was selected for slaughter based on the mean weight of its experimental unit. The birds were slaughtered using the cervical displacement method followed by exsanguination.

To collect the liver, an incision was made in the abdominal cavity of the bird to expose the viscera.

After plucking and cleaning, a single sample of breast muscle weighing approximately $30 \mathrm{~g}$ was collected from each experimental unit.

Litter samples were collected from a previously established site at the centre of each experimental unit (pen) to determine the mineral ( $\mathrm{Mn}, \mathrm{Zn}, \mathrm{Fe}, \mathrm{Cu}$ and $\mathrm{Se}$ ) concentration in the litter. All of the material contained within a $90-\mathrm{cm}^{2}$ piece of plastic lining was collected.

Samples of the right tibia, liver, and right portion of the breast musculature from each bird and litter of each experimental unit were collected and placed separately in plastic bags labelled with the corresponding treatments and stored in a freezer at $-20^{\circ} \mathrm{C}$.

The tibia were washed, cleaned of all residual tissue and dried at $60{ }^{\circ} \mathrm{C}$ for $72 \mathrm{~h}$. Subsequently, pre-degreasing was performed for $4 \mathrm{~h}$ with petroleum ether in a glass vessel. The tibia were then ground, and a sample of each was removed (eight samples per treatment, totalling 96 samples), dried for $12 \mathrm{~h}$ at $105{ }^{\circ} \mathrm{C}$ to determine dry mass and then ashed in a muffle furnace $\left(600{ }^{\circ} \mathrm{C}\right.$ for $4 \mathrm{~h}$ ) to determine ash content. Calcium and $\mathrm{P}$ were determined after wet-ash digestion with nitric and perchloric acids according to the 935.13 method (AOAC, 2000). Calcium in wet-ashed samples was determined by the atomic absorption spectrophotometric method 968.08 (AOAC, 2000) using an atomic absorption spectrometer (AAnalyst 300). Phosphorus concentration was determined using a colorimetric assay (Fiske and Subbarow, 1925). Acid molybdate and Fiske's SubbaRow reducer solution were added to wet-ash samples to perform a phosphor-molybdenum complex. Color intensity was proportional to $\mathrm{P}$ concentration and was determined with a spectrophotometer using absorbance at $620 \mathrm{~nm}$ (SpectraCount, Model \#AS1000). The analyses were performed at the Animal Nutrition Laboratory in Viçosa (20 $45^{\prime} 14^{\prime \prime} \mathrm{S}, 42^{\circ} 52^{\prime} 53^{\prime \prime} \mathrm{W}$ and $648.74 \mathrm{~m}$ of altitude), in the state of Minas Gerais, Brazil.

Samples of diets, liver, breast and litter were sent to a laboratory $\left(54^{\prime} 23^{\prime \prime} \mathrm{S}, 47^{\circ} 3^{\prime} 42^{\prime \prime} \mathrm{W}\right.$ and $760 \mathrm{~m}$ of altitude, Campinas, in the state of São Paulo, Brazil) to determine the concentrations of $\mathrm{Mn}, \mathrm{Zn}, \mathrm{Fe}, \mathrm{Cu}$ and Se. For this the frozen samples of liver and breast were packed with ice in a Styrofoam box to maintain their physiochemical characteristics. The litter samples were dried for $72 \mathrm{~h}$ in a ventilated oven at $60{ }^{\circ} \mathrm{C}$ and were then ground $(0.5 \mathrm{~mm})$.

Zinc, $\mathrm{Mn}, \mathrm{Fe}, \mathrm{Cu}$ and Se concentrations in liver, breast, litter and diet samples were determined following the methods described by AOAC (1984). An aliquot of $0.5 \mathrm{~g}$ of diets, tissues and litter samples were weighed on the analytical balance and added $5 \mathrm{ml}$ of 4:1 nitroperchloric acid solution (4 parts nitric acid and 1 part perchloric acid). The samples were heated and digested at $200{ }^{\circ} \mathrm{C}$ in the digester block and the residue was filtrated through quantitative paper $17.5 \mu \mathrm{m}$ pore) and completed for $50 \mathrm{~mL}$ with distilled water. This solution was analyzed in an atomic absorption spectrophotometer (AAS) to obtain the mineral concentrations ( $\mathrm{Mn}, \mathrm{Fe}, \mathrm{Zn}$ and $\mathrm{Cu}$ ) and for Se concentrations the graphite furnace atomic absorption spectroscopy (GFAAS) was used.

Data were analysed using the GLM procedure (SAS v. 9.3). Pens containing 26 birds were considered as the experimental units. The model included the main effects of $\mathrm{Ca}$ level and micromineral supplementation and their interaction, as described below:

$y_{i j k}=\mu+C a_{i}+M S_{j}+(C a \times M S)_{i j}+\varepsilon_{i j k} i=1, \ldots, a_{i} j=$ $1, \ldots, b ; k=1, \ldots, n$,

where: $y_{\mathrm{ijk}}=$ observation $k$ in level $i$ of factor $C a$ and level $j$ of factor $M S_{;} \mu=$ the overall mean; $C a_{i}=$ the effect of level $i$ of the factor Ca level, $M S_{j}=$ the effect of level $j$ of the factor Mineral supplementation; $(\mathrm{Ca} \times M S)_{i j}$ $=$ the effect of the interaction of level $i$ of factor $C a$ with level $j$ of factor $M S ; \varepsilon_{i j k}=$ residual random error; $a=$ the number of levels of factor $C a ; b=$ the number of levels of factor $M S ; n=$ the number of observations for each $\mathrm{Ca} \times M S$ combination.

The isolated effects of mineral supplementation were analysed by orthogonal polynomial contrasts, and the isolated effects of Ca level were compared using Tukey's means test. The effects were considered significant at $p<0.05$.

\section{Results}

The interaction between MS and Ca level was significant $(p<0.05)$ for BWG, FI and F:G (Table 3). At the Ca level of $10 \mathrm{~g} \mathrm{~kg}^{-1}$, BWG showed a quadratic response to $\mathrm{MS}$, with $\mathrm{Y}=0.435+1.141 \mathrm{X}-0.622 \mathrm{X}^{2}\left(\mathrm{R}^{2}=0.86\right)$. The greatest BWG was observed at the MS level of 0.917 $\mathrm{g} \mathrm{kg}^{-1}$. MS did not influence BWG at Ca levels of 8 and $12 \mathrm{~g} \mathrm{~kg}^{-1}$.

At a Ca level of $8 \mathrm{~g} \mathrm{~kg}^{-1}$, FI showed a quadratic response to $\mathrm{MS}$, with $\mathrm{Y}=2.617-3.708 \mathrm{X}+2.481 \mathrm{X}^{2}$ $\left(\mathrm{R}^{2}=0.89\right)$. The lowest feed intake was observed at the MS level of $0.747 \mathrm{~g} \mathrm{~kg}^{-1}$. However, at the Ca level of 10 
$\mathrm{g} \mathrm{kg}^{-1}$, FI showed a linear relationship with MS, represented by the equation $\mathrm{Y}=1.024+0.293 \mathrm{X}\left(\mathrm{R}^{2}=0.84\right)$. At the MS level of $0.92 \mathrm{~g} \mathrm{~kg}^{-1}$, FI was lower at dietary Ca levels of 10 and $12 \mathrm{~g} \mathrm{~kg}^{-1}$.

At the Ca level of $8 \mathrm{~g} \mathrm{~kg}^{-1}, \mathrm{~F}: \mathrm{G}$ showed a quadratic response to $\mathrm{MS}$, according to the equation $\mathrm{Y}=2.429$ $2.959 \mathrm{X}+1.981 \mathrm{X}^{2}\left(\mathrm{R}^{2}=0.97\right)$. The lowest feed-to-gain ratio was observed at the MS level of $0.747 \mathrm{~g} \mathrm{~kg}^{-1}$. In the same way, at the MS level of $0.92 \mathrm{~g} \mathrm{~kg}^{-1}, \mathrm{~F}: \mathrm{G}$ was lower at dietary Ca levels of 10 and $12 \mathrm{~g} \mathrm{~kg}^{-1}$.

Viability did not interact with and was not independently affected by the factors analysed ( $p>0.05)$.

Additionally, MS had no independent or interactive effect on the percentages of $\mathrm{Ca}, \mathrm{P}$ and ash in the tibia $(p>0.05)$. However, increasing the dietary Ca level resulted in increased $\mathrm{Ca}, \mathrm{P}$ and ash concentrations in this bone $(p<0.05)$ (Table 4$)$.

The MS and Ca independently influenced the concentrations of $\mathrm{Mn}$ and $\mathrm{Zn}$ in the liver and MS levels influenced the Se liver concentration $(p<0.05)$ (Table $5)$. The MS level was positively and linearly correlated with Se and Mn concentrations $(p<0.05)$ in the liver, while a quadratic relationship was observed for the $\mathrm{Zn}$

Table 3 - Influence of dietary $\mathrm{Ca}$ and MS on body weight gain (BWG), feed intake (FI), feed-to-gain ratio (F:G), viability (Viab.)1.

\begin{tabular}{|c|c|c|c|c|c|}
\hline \multicolumn{2}{|c|}{ Treatments } & \multicolumn{4}{|c|}{ Variables } \\
\hline $\mathrm{Ca}$ & MS & BWG & $\mathrm{Fl}$ & $F: G$ & Viab. \\
\hline \multicolumn{2}{|c|}{$\mathrm{g} \mathrm{kg}^{-1} \longrightarrow$} & 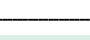 & $g$ & intake/gain & $\%$ \\
\hline \multirow{4}{*}{$8^{3,5}$} & 0.62 & 0.936 & 1.268 & 1.354 & 97.59 \\
\hline & 0.72 & 0.938 & 1.247 & 1.330 & 99.04 \\
\hline & 0.82 & $0.926^{z}$ & 1.232 & 1.330 & 97.48 \\
\hline & 0.92 & 0.946 & $1.310^{\mathrm{w}}$ & $1.385^{\mathrm{w}}$ & 97.60 \\
\hline \multirow{4}{*}{$10^{2,4}$} & 0.62 & 0.907 & 1.212 & 1.336 & 98.56 \\
\hline & 0.72 & 0.922 & 1.215 & 1.317 & 99.04 \\
\hline & 0.82 & $0.964^{w}$ & 1.282 & 1.331 & 97.12 \\
\hline & 0.92 & 0.955 & $1.286^{z w}$ & $1.348^{2 \mathrm{w}}$ & 98.56 \\
\hline \multirow{4}{*}{12} & 0.62 & 0.934 & 1.256 & 1.346 & 97.67 \\
\hline & 0.72 & 0.929 & 1.235 & 1.330 & 99.04 \\
\hline & 0.82 & $0.928^{z}$ & 1.226 & 1.320 & 98.56 \\
\hline & 0.92 & 0.935 & $1.233^{z}$ & $1.320^{z}$ & 98.08 \\
\hline \multirow{4}{*}{ MS } & 0.62 & 0.926 & 1.245 & 1.345 & 97.94 \\
\hline & 0.72 & 0.930 & 1.232 & 1.326 & 99.04 \\
\hline & 0.82 & 0.940 & 1.247 & 1.327 & 97.72 \\
\hline & 0.92 & 0.945 & 1.277 & 1.351 & 98.08 \\
\hline \multirow{3}{*}{$\mathrm{Ca}$} & 8 & 0.937 & 1.264 & 1.350 & 97.93 \\
\hline & 10 & 0.937 & 1.249 & 1.333 & 98.32 \\
\hline & 12 & 0.931 & 1.238 & 1.329 & 98.33 \\
\hline \multirow{4}{*}{ ANOVA } & MS & 0.129 & 0.005 & 0.004 & 0.337 \\
\hline & $\mathrm{Ca}$ & 0.727 & 0.051 & 0.012 & 0.754 \\
\hline & $\mathrm{MS} \times \mathrm{Ca}$ & 0.045 & $<0.001$ & 0.032 & 0.932 \\
\hline & CV\%* & 3.352 & 3.431 & 2.157 & 2.807 \\
\hline
\end{tabular}

${ }^{1}$ Means represent eight experimental units with 26 birds per experimental unit; ${ }^{2} \mathrm{BWG}{ }=0.435+1.141 \mathrm{X}-0.622 \mathrm{X}^{2}\left(\mathrm{R}^{2}=0.86\right) ;{ }^{3} \mathrm{FI}=2.617-3.708+$ $2.481 \mathrm{X}^{2}\left(\mathrm{R}^{2}=0.89\right) ;{ }^{4} \mathrm{FI} \mathrm{Ca}_{\mathrm{Ca} 0}=1.024+0.293 \mathrm{X}\left(\mathrm{R}^{2}=0.84\right) ;{ }^{5} \mathrm{~F}: \mathrm{G}_{\mathrm{cas}}=2.429$ $-2.959 X+1.981 X^{2}\left(R^{2}=0.97\right) ; z$ and wmeans represents by different letters in the same column are different from each other $(p<0.05)$ consider the effect of Ca levels in MS levels; *Coefficient of variation. concentration $(p<0.05)$. These three relationships can be represented by the equations $\mathrm{Y}=0.189+0.912 \mathrm{X}$ $\left(\mathrm{R}^{2}=0.99\right), \mathrm{Y}=5.284+6.020 \mathrm{X}\left(\mathrm{R}^{2}=0.94\right)$ and $\mathrm{Y}=$ $38.937+162.288 \mathrm{X}-78.00 \mathrm{X}^{2}\left(\mathrm{R}^{2}=0.83\right)$, respectively. According to this equation, the highest $\mathrm{Zn}$ deposition in the liver occurs with $1.04 \mathrm{~g} \mathrm{~kg}^{-1}$ of MS. However, as this level is outside the MS range tested here, this equation is not representative of high $\mathrm{Zn}$ deposition in the liver. Higher Mn concentrations were observed at Ca levels of 8 and $10 \mathrm{~g} \mathrm{~kg}^{-1}$.

The concentrations of $\mathrm{Cu}$ and Fe were affected by interaction between the MS and Ca levels $(p<$ 0.05; Table 5). At Ca levels of 8 and $10 \mathrm{~g} \mathrm{~kg}^{-1}, \mathrm{MS}$ produced a linear increase in liver $\mathrm{Cu}$ concentration, according to the equations $\mathrm{Y}=-65.497+137.007 \mathrm{X}$ $\left(\mathrm{R}^{2}=0.96\right)$ and $\mathrm{Y}=-43.278+116.803 \mathrm{X}\left(\mathrm{R}^{2}=0.95\right)$, respectively. At the lowest MS level $\left(0.62 \mathrm{~g} \mathrm{~kg}^{-1}\right)$, the highest liver $\mathrm{Cu}$ concentration was observed at a $\mathrm{Ca}$ level of $12 \mathrm{~g} \mathrm{~kg}^{-1}$.

For Fe in liver, at a Ca level of $12 \mathrm{~g} \mathrm{~kg}^{-1}, \mathrm{MS}$ had a quadratic effect on the liver Fe concentration, with $\mathrm{Y}=$ $2124.465-4544.524 \mathrm{X}+3106.109 \mathrm{X}^{2}\left(\mathrm{R}^{2}=0.92\right)$, with the lowest Fe deposition observed at $0.73 \mathrm{~g} \mathrm{~kg}^{-1} \mathrm{MS}$. At a $0.72 \mathrm{~g} \mathrm{~kg}^{-1} \mathrm{MS}$, the highest liver Fe deposition was observed at $8 \mathrm{~g} \mathrm{~kg}^{-1} \mathrm{Ca}$.

Table 4 - Dry basis percentages of calcium (Ca), phosphorus (P) and ash in the tibia of birds under different treatments ${ }^{1}$.

\begin{tabular}{|c|c|c|c|c|}
\hline \multicolumn{2}{|c|}{ Treatments } & \multicolumn{3}{|c|}{ Variables } \\
\hline $\mathrm{Ca}$ & MS & $\mathrm{Ca}$ & $P$ & Ash \\
\hline 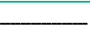 & -1 & & - $\%$ & \\
\hline \multirow{4}{*}{8} & 0.62 & 16.61 & 9.48 & 51.61 \\
\hline & 0.72 & 16.67 & 9.55 & 51.83 \\
\hline & 0.82 & 16.51 & 9.85 & 52.10 \\
\hline & 0.92 & 16.14 & 9.47 & 51.77 \\
\hline \multirow{4}{*}{10} & 0.62 & 16.19 & 10.08 & 52.54 \\
\hline & 0.72 & 16.61 & 10.13 & 52.53 \\
\hline & 0.82 & 17.17 & 9.89 & 52.23 \\
\hline & 0.92 & 17.30 & 10.11 & 52.34 \\
\hline \multirow{4}{*}{12} & 0.62 & 17.05 & 9.65 & 52.31 \\
\hline & 0.72 & 17.07 & 9.76 & 52.84 \\
\hline & 0.82 & 17.08 & 10.06 & 52.55 \\
\hline & 0.92 & 17.17 & 9.84 & 53.29 \\
\hline \multirow{4}{*}{ MS } & 0.62 & 16.64 & 9.74 & 52.15 \\
\hline & 0.72 & 16.78 & 9.81 & 52.40 \\
\hline & 0.82 & 16.92 & 9.93 & 52.29 \\
\hline & 0.92 & 16.87 & 9.81 & 52.47 \\
\hline \multirow{3}{*}{$\mathrm{Ca}$} & 8 & $16.37^{b}$ & $9.59^{c}$ & $51.83^{b}$ \\
\hline & 10 & $16.82^{a}$ & $10.05^{a}$ & $52.41^{a}$ \\
\hline & 12 & $17.09^{a}$ & $9.83^{b}$ & $52.75^{a}$ \\
\hline \multirow{4}{*}{ ANOVA } & MS & 0.194 & 0.326 & 0.296 \\
\hline & $\mathrm{Ca}$ & 0.002 & $<0.001$ & $<0.001$ \\
\hline & $\mathrm{MS} \times \mathrm{Ca}$ & 0.242 & 0.153 & 0.066 \\
\hline & CV\%* & 4.703 & 3.740 & 1.143 \\
\hline
\end{tabular}

${ }^{1}$ Means represent eight experimental units with 26 birds per experimental unit; $a, b, c$ Means within the same column that have different letters are significantly different from each other $(p<0.05)$; ${ }^{*}$ Coefficient of variation. 
Table 5 - Treatment effects on the dry basis concentrations of the micronutrients selenium (Se), copper (Cu), iron (Fe), manganese $(\mathrm{Mn})$ and zinc $(\mathrm{Zn})$ in broiler livers ${ }^{1}$.

\begin{tabular}{|c|c|c|c|c|c|c|}
\hline \multicolumn{2}{|c|}{ Treatments } & \multicolumn{5}{|c|}{ Minerals } \\
\hline $\mathrm{Ca}$ & MS & $\mathrm{Se}$ & $\mathrm{Cu}$ & $\mathrm{Fe}$ & $\mathrm{Mn}$ & $\mathrm{Zn}$ \\
\hline \multicolumn{2}{|c|}{$-\mathrm{g} \mathrm{kg}^{-1}-$} & & & $n n m$ & & \\
\hline \multirow{4}{*}{$8^{2}$} & 0.62 & 0.743 & 22.176 & 517.785 & 9.094 & 111.480 \\
\hline & 0.72 & 0.818 & 27.972 & 555.503 & 10.120 & 108.015 \\
\hline & 0.82 & 0.979 & 49.017 & 474.627 & 10.521 & 115.102 \\
\hline & 0.92 & 0.983 & 60.830 & 492.504 & 10.665 & 123.090 \\
\hline \multirow{4}{*}{$10^{3}$} & 0.62 & 0.779 & 30.545 & 502.226 & 9.208 & 108.332 \\
\hline & 0.72 & 0.829 & 41.050 & 436.407 & 9.998 & 110.564 \\
\hline & 0.82 & 0.919 & 47.828 & 525.005 & 10.569 & 115.685 \\
\hline & 0.92 & 1.031 & 67.220 & 542.522 & 10.855 & 118.898 \\
\hline \multirow{4}{*}{$12^{4}$} & 0.62 & 0.717 & 56.151 & 506.252 & 8.310 & 111.773 \\
\hline & 0.72 & 0.928 & 40.976 & 446.404 & 9.075 & 118.865 \\
\hline & 0.82 & 0.920 & 45.765 & 502.715 & 10.207 & 136.517 \\
\hline & 0.92 & 1.054 & 48.944 & 567.110 & 10.412 & 121.812 \\
\hline \multirow{4}{*}{ MS } & 0.62 & 0.746 & 36.291 & 508.754 & 8.871 & 110.529 \\
\hline & 0.72 & 0.858 & 36.666 & 479.438 & 9.731 & 112.481 \\
\hline & 0.82 & 0.939 & 47.537 & 500.782 & 10.432 & 122.435 \\
\hline & 0.92 & 1.023 & 58.998 & 534.046 & 10.644 & 121.267 \\
\hline \multirow{3}{*}{$\mathrm{Ca}$} & 8 & 0.881 & 39.999 & 510.105 & $10.100^{a}$ & $114.422^{\mathrm{a}}$ \\
\hline & 10 & 0.889 & 46.661 & 501.540 & $10.158^{a}$ & $113.370^{a}$ \\
\hline & 12 & 0.905 & 47.959 & 505.620 & $9.501^{\mathrm{b}}$ & $122.242^{\mathrm{a}}$ \\
\hline \multirow{4}{*}{ ANOVA } & MS & $<0.001^{\llcorner 1}$ & $<0.001$ & 0.170 & $<0.001^{\llcorner 2}$ & $0.011^{\circ}$ \\
\hline & $\mathrm{Ca}$ & 0.832 & 0.142 & 0.921 & 0.008 & 0.040 \\
\hline & $\mathrm{MS} \times \mathrm{Ca}$ & 0.669 & 0.004 & 0.034 & 0.878 & 0.349 \\
\hline & CV\%* & 17.99 & 38.09 & 16.67 & 9.22 & 12.82 \\
\hline
\end{tabular}

${ }^{1}$ Means represent eight experimental units with 26 birds per experimental unit; ${ }^{\llcorner}{ }^{L}$ Linear effect $(Y=0.189+0.912 X)$; ${ }^{2}$ Linear effect $(Y=5.284+6.020 X)$; QQuadratic effect $\left(Y=38.937+162.288 X-78.00 X^{2}\right)$; a,b Means within the same row that have different letters are significantly different from each other; ${ }^{2} \mathrm{Cu}$ liver ${ }_{\mathrm{Cas}}=-65.497+137.007 \mathrm{X}\left(\mathrm{R}^{2}=0.96\right) ;{ }^{3} \mathrm{Cu}$ liver ${ }_{\mathrm{c} 10}=-43.278+$ $116.803 X^{2}\left(R^{2}=0.95\right) ;{ }^{4}$ Fe liver ${ }^{c}=2124.465-4544.524 X^{2}+3106.109 X^{2}$ $\left(R^{2}=0.92\right) ;{ }^{*}$ Coefficient of variation.

The MS levels independently influenced the Mn and $\mathrm{Zn}$ concentrations in the breast muscle $(p<0.05)$ (Table 6). The Mn concentration in the breast showed a quadratic response to MS, where $\mathrm{Y}=-0.723+3.536 \mathrm{X}$ $-2.10 \mathrm{X}^{2}\left(\mathrm{R}^{2}=0.84\right)$. The highest $\mathrm{Mn}$ deposition was observed at $0.84 \mathrm{~g} \mathrm{~kg}^{-1} \mathrm{MS}$. Moreover, the concentration of $\mathrm{Zn}$ in the breast increased linearly with $\mathrm{MS}$, with $\mathrm{Y}=$ $26.430+6.807 \mathrm{X}\left(\mathrm{R}^{2}=0.77\right)$. The dietary Ca level influenced independently the Fe and Mn concentration in the breast, with the lowest levels observed at $10 \mathrm{~g} \mathrm{~kg}^{-1} \mathrm{Ca}$.

The $\mathrm{Se}$ and $\mathrm{Cu}$ concentrations in the breast were affected by the interaction between MS and Ca levels $(p$ $<0.05$; Table 6). At $8 \mathrm{~g} \mathrm{~kg}^{-1} \mathrm{Ca}$, the Se concentration in the breast showed a quadratic response to MS, with $\mathrm{Y}$ $=-0.831+2.666 \mathrm{X}-1.625 \mathrm{X}^{2}\left(\mathrm{R}^{2}=0.62\right)$. The highest concentration was observed at $0.83 \mathrm{~g} \mathrm{~kg}^{-1} \mathrm{MS}$. At the Ca levels of 10 and $12 \mathrm{~g} \mathrm{~kg}^{-1}$, MS produced a linear increase in breast Se concentrations, according to the equations $\mathrm{Y}$ $=0.057+0.254 \mathrm{X}\left(\mathrm{R}^{2}=0.88\right)$ and $\mathrm{Y}=0.032+0.315 \mathrm{X}$ $\left(\mathrm{R}^{2}=0.96\right)$, respectively.

At $12 \mathrm{~g} \mathrm{~kg}^{-1} \mathrm{Ca}$, the breast $\mathrm{Cu}$ concentration showed a quadratic response to MS, according to the
Table 6 - Treatment effects on the dry basis concentrations of the micronutrients selenium (Se), copper ( $\mathrm{Cu}$ ), iron (Fe), manganese $(\mathrm{Mn})$ and zinc $(\mathrm{Zn})$ in broiler breasts ${ }^{1}$.

\begin{tabular}{|c|c|c|c|c|c|c|}
\hline \multicolumn{2}{|c|}{ Treatments } & \multicolumn{5}{|c|}{ Minerals (ppm) } \\
\hline $\mathrm{Ca}$ & MS & $\mathrm{Se}$ & $\mathrm{Cu}$ & $\mathrm{Fe}$ & $\mathrm{Mn}$ & $\mathrm{Zn}$ \\
\hline \multicolumn{2}{|c|}{$\mathrm{g} \mathrm{kg}^{-1} \longrightarrow$} & & & piाi & & \\
\hline \multirow{4}{*}{$8^{2}$} & 0.62 & 0.219 & 8.633 & 25.798 & 0.693 & 31.356 \\
\hline & 0.72 & 0.233 & $9.332^{\mathrm{t}}$ & 28.158 & 0.727 & 31.010 \\
\hline & 0.82 & 0.307 & $6.936^{\dagger}$ & 29.149 & 0.834 & 31.145 \\
\hline & 0.92 & $0.255^{z}$ & $8.875^{\mathrm{h}}$ & 26.678 & 0.793 & 31.928 \\
\hline \multirow{4}{*}{$10^{3}$} & 0.62 & 0.204 & 10.893 & 25.776 & 0.668 & 31.730 \\
\hline & 0.72 & 0.258 & $5.821^{t}$ & 23.795 & 0.677 & 29.474 \\
\hline & 0.82 & 0.263 & $7.557^{\dagger}$ & 22.710 & 0.699 & 32.993 \\
\hline & 0.92 & $0.287^{w}$ & $8.564^{\mathrm{h}}$ & 22.113 & 0.639 & 32.303 \\
\hline \multirow{4}{*}{$12^{4,5}$} & 0.62 & 0.233 & 9.011 & 21.285 & 0.650 & 30.186 \\
\hline & 0.72 & 0.255 & $17.703^{s}$ & 25.743 & 0.729 & 31.474 \\
\hline & 0.82 & 0.280 & $17.994^{\mathrm{e}}$ & 26.587 & 0.830 & 31.997 \\
\hline & 0.92 & $0.329^{w}$ & $17.233 \mathrm{~g}$ & 26.051 & 0.803 & 34.459 \\
\hline \multirow{4}{*}{ MS } & 0.62 & 0.219 & 9.512 & 24.286 & 0.670 & 31.091 \\
\hline & 0.72 & 0.249 & 10.952 & 25.899 & 0.711 & 30.653 \\
\hline & 0.82 & 0.283 & 10.829 & 26.149 & 0.788 & 32.045 \\
\hline & 0.92 & 0.291 & 11.557 & 24.947 & 0.745 & 32.896 \\
\hline \multirow{3}{*}{$\mathrm{Ca}$} & 8 & 0.253 & 8.444 & $27.449^{a}$ & $0.762^{\mathrm{a}}$ & 31.360 \\
\hline & 10 & 0.253 & 8.209 & $23.599^{b}$ & $0.671^{b}$ & 31.625 \\
\hline & 12 & 0.274 & 15.485 & $24.916^{a}$ & $0.753^{a}$ & 32.029 \\
\hline \multirow{4}{*}{ ANOVA } & MS & $<0.001$ & 0.594 & 0.633 & $0.001^{Q}$ & 0.027 \\
\hline & $\mathrm{Ca}$ & 0.087 & $<0.001$ & 0.023 & 0.001 & 0.618 \\
\hline & $\mathrm{MS} \times \mathrm{Ca}$ & 0.036 & 0.008 & 0.365 & 0.222 & 0.216 \\
\hline & CV\%* & 16.59 & 49.39 & 21.99 & 14.11 & 8.65 \\
\hline
\end{tabular}

${ }^{1}$ Means represent eight experimental units with 26 birds per experimental unit; QQuadratic effect $\left(Y=-0.723+3.536 \mathrm{X}-2.10 \mathrm{X}^{2}\right)$; Linear effect $(\mathrm{Y}=26.430$ $+6.807 X)$; ab Means within the same column that have different letters are significantly different from each other $(p<0.05)$; ${ }^{2}$ Se breast ${ }_{\text {cas }}=-0.831+$ $2.666 \mathrm{X}-1.625 \mathrm{X}^{2}\left(\mathrm{R}^{2}=0.62\right) ;{ }^{3} \mathrm{Se}$ breast ${ }_{\mathrm{Cal1}}=\mathrm{Y}=0.057^{\mathrm{ca} 8}+0.254 \mathrm{X}\left(\mathrm{R}^{2}\right.$ $=0.88) ;{ }^{4} \mathrm{Se}$ breast $=0.032+0.315 \mathrm{X}\left(\mathrm{R}^{2}=0.96\right) ;{ }^{5} \mathrm{Cu}$ breast ${ }_{\text {cil }}=$ $-140.908+388.932 X-236.347 X^{2}\left(R^{2}=0.95\right) ; z$ and $w, s$ and $t, g$ and $h, e$ and $f$ means represents by different letters in the same column are different from each other $(p<0.05)$ consider the effect of $\mathrm{Ca}$ levels in MS levels; ${ }^{*}$ Coefficient of variation.

equation $\mathrm{Y}=-140.908+388.932 \mathrm{X}-236.347 \mathrm{X}^{2}\left(\mathrm{R}^{2}=\right.$ 0.95). The highest $\mathrm{Cu}$ concentration was observed at $0.82 \mathrm{~g} \mathrm{~kg}^{-1}$ MS.

At the MS level of $0.92 \mathrm{~g} \mathrm{~kg}^{-1}$, the highest breast Se concentrations were observed at 10 and $12 \mathrm{~g} \mathrm{~kg}^{-1} \mathrm{Ca}$. At the MS levels of $0.72,0.82$ and $0.92 \mathrm{~g} \mathrm{~kg}^{-1}$, the highest breast $\mathrm{Cu}$ concentrations were found at $12 \mathrm{~g} \mathrm{~kg}^{-1} \mathrm{Ca}$.

The $\mathrm{Cu}$ and $\mathrm{Fe}$ concentrations in the litter increased linearly with MS $(p<0.05)$ according to the equations $\mathrm{Y}=20.851+15.915 \mathrm{X}\left(\mathrm{R}^{2}=0.08\right)$ and $\mathrm{Y}=$ $964.071+768.073 \mathrm{X}\left(\mathrm{R}^{2}=0.18\right)$, respectively (Table 7$)$.

The Ca level affected the Fe concentration in the litter $(p<0.05)$, with the lowest value observed at $10 \mathrm{~g}$ $\mathrm{kg}^{-1} \mathrm{Ca}$ (Table 7).

The $\mathrm{Se}, \mathrm{Mn}$ and $\mathrm{Zn}$ concentrations in the litter showed interactive effects with MS and the Ca level ( $p$ $<0.05$ ) (Table 7).

For $\mathrm{Se}$, at $10 \mathrm{~g} \mathrm{~kg}^{-1} \mathrm{Ca}$, MS showed a quadratic effect, $\mathrm{Y}=-1.245+3.678 \mathrm{X}-2.219 \mathrm{X}^{2}\left(\mathrm{R}^{2}=0.99\right)$, with the highest concentration found at $0.829 \mathrm{~g} \mathrm{~kg}^{-1} \mathrm{MS}$. At 
Table 7 - Treatment effects on the dry mass concentrations of the micronutrients selenium (Se), copper (Cu), iron (Fe), manganese $(\mathrm{Mn})$ and zinc $(\mathrm{Zn})$ excreted in litter ${ }^{1}$.

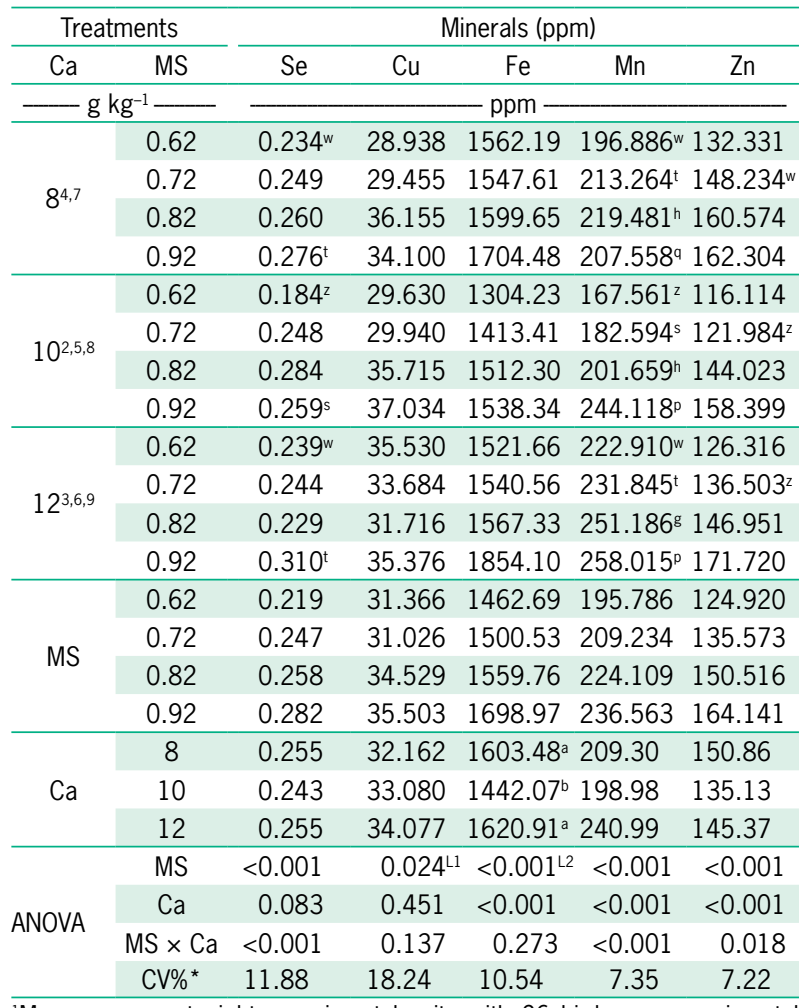

${ }^{1}$ Means represent eight experimental units with 26 birds per experimental unit; ${ }^{L 1}$ Linear effect $(Y=20.851+15.915 X)$; L2Linear effect $(Y=964.071$ $+768.073 \mathrm{X})$; $\mathrm{ab}$ Means within the same column that have different letters are significantly different from each other $(p<0.05)$; ${ }^{2}$ Se litter ${ }_{\text {aal }}=-1.245+$ $3.678 \mathrm{X}-2.219 \mathrm{X}^{2}\left(\mathrm{R}^{2}=0.99\right) ;{ }^{3}$ Se litter ${ }^{2}=0.102+0.19 \mathrm{X}\left(\mathrm{R}^{2}=0.48\right)$; ${ }^{4} \mathrm{Mn}$ litter ${ }_{\mathrm{Cas}}=-230.792+1127.829 \mathrm{X}-707.531 \mathrm{X}^{2}\left(\mathrm{R}^{2}=0.99\right) ;{ }^{5} \mathrm{Mn}$ litter ${ }^{2}=7.458+248.734 X\left(R^{2}=0.94\right) ; 6 \mathrm{Mn}$ litter ${ }^{\mathrm{Ca} 12}=145.004+124.656 \mathrm{X}\left(\mathrm{R}^{2}\right.$ $=0.97) ;{ }^{7} \mathrm{Zn}$ litter $=72.122+102.258 \mathrm{X}\left(\mathrm{R}^{2}=0.91\right) ;{ }^{8} \mathrm{Zn}$ litter $=20.482$ $+148.894 \mathrm{X}\left(\mathrm{R}^{2}=0.96\right) ;{ }^{9} \mathrm{Zn}$ litter ${ }_{\mathrm{Ca} 2}=32.444+146.660 \mathrm{X}\left(\mathrm{R}^{2}=0.94\right) ;{ }^{2}$ and $\mathrm{w}, \mathrm{s}$ and $\mathrm{t}, \mathrm{g}$ and $\mathrm{h}, \mathrm{p}$ and $\mathrm{aMeans}$ represents by different letters in the same column are different from each other $(p<0.05)$ consider the effect of Ca levels in MS levels; *Coefficient of variation.

$12 \mathrm{~g} \mathrm{~kg}^{-1} \mathrm{Ca}$, increasing MS produced a linear increase in litter Se concentration, according to the equation $\mathrm{Y}=$ $0.102+0.19 \mathrm{X}\left(\mathrm{R}^{2}=0.48\right)$.

With respect to the Mn concentration in the litter, MS had a quadratic effect at $8 \mathrm{~g} \mathrm{~kg}^{-1} \mathrm{Ca}$, represented by $\mathrm{Y}=-230.792+1127.829 \mathrm{X}-707.531 \mathrm{X}^{2}\left(\mathrm{R}^{2}=0.99\right)$. The highest litter Mn concentration was observed at $0.797 \mathrm{~g}$ $\mathrm{kg}^{-1} \mathrm{MS}$. At 10 and $12 \mathrm{~g} \mathrm{~kg}^{-1} \mathrm{Ca}$, MS had a linear effect on litter Mn concentration, according to the equations $\mathrm{Y}=7.458+248.734 \mathrm{X}\left(\mathrm{R}^{2}=0.94\right)$ and $\mathrm{Y}=145.004+$ 124.656X $\left(\mathrm{R}^{2}=0.97\right)$, respectively.

At all Ca levels $\left(8,10\right.$ and $\left.12 \mathrm{~g} \mathrm{~kg}^{-1}\right)$, the litter $\mathrm{Zn}$ concentration increased linearly with $\mathrm{MS}$, according to the equations $\mathrm{Y}=72.122+102.258 \mathrm{X}\left(\mathrm{R}^{2}=0.91\right), \mathrm{Y}$ $=20.482+148.894 \mathrm{X}\left(\mathrm{R}^{2}=0.96\right)$ and $\mathrm{Y}=32.444+$ 146.660X $\left(\mathrm{R}^{2}=0.94\right)$, respectively.

At 0.62 and $0.92 \mathrm{~g} \mathrm{~kg}^{-1} \mathrm{MS}$, the lowest litter Se concentration was observed at $10 \mathrm{~g} \mathrm{~kg}^{-1} \mathrm{Ca}$.
The lowest litter Mn concentrations at 0.62 and $0.72 \mathrm{~g} \mathrm{~kg}^{-1} \mathrm{MS}$ were also observed at $10 \mathrm{~g} \mathrm{~kg}^{-1} \mathrm{Ca}$. At 0.82 $\mathrm{g} \mathrm{kg}^{-1} \mathrm{MS}$, the lowest Mn concentrations were found at 8 and $10 \mathrm{~g} \mathrm{~kg}^{-1} \mathrm{Ca}$. At $0.92 \mathrm{~g} \mathrm{~kg}^{-1} \mathrm{MS}$, the lowest litter $\mathrm{Mn}$ concentration was found at $8 \mathrm{~g} \mathrm{~kg}^{-1} \mathrm{Ca}$.

At $0.72 \mathrm{~g} \mathrm{~kg}^{-1} \mathrm{MS}$ alone, the lowest $\mathrm{Zn}$ concentration was found at 10 and $12 \mathrm{~g} \mathrm{~kg}^{-1} \mathrm{Ca}$.

\section{Discussion}

At all MS levels in the diets used in this study, the micromineral concentrations per kilogram of feed were lower than those recommended by the NRC, (1994) and Rostagno et al., (2011).

Research into minerals from inorganic sources has demonstrated an antagonistic relationship between the macromineral $\mathrm{Ca}$ and certain trace microminerals, such as $\mathrm{Mn}, \mathrm{Fe}$ and $\mathrm{Zn}$. However, many studies have reported that this antagonistic relationship may be reduced by supplementing these microminerals using organic trace minerals sources at levels much lower than those recommended.

In the present study, the observed responses of BWG, FI and F:G confirm the hypothesis of an interaction between the levels of dietary $\mathrm{Ca}$ and trace micromineral supplementation during the starter phase of broiler production.

When $10 \mathrm{~g}$ Ca per kilogram of diet was used, a mineral supplementation level of $0.82 \mathrm{~g}$ per $\mathrm{kg}$ of diet produced the largest BWG. At Ca levels above or below the recommendation, BWG was not affected, indicating the importance of adequately defining Ca levels as well as supplementing microminerals from organic sources.

The observed FI responses were distinct and also dependent on the levels of Ca and MS. At the lowest Ca concentrations (8 and $\left.10 \mathrm{~g} \mathrm{~kg}^{-1}\right)$, the highest MS level $(0.92$ $\mathrm{g} \mathrm{kg}^{-1}$ ) promoted greater FI, which showed a quadratic response and a linear increase with MS at these levels. At the highest $\mathrm{Ca}$ concentration $\left(12 \mathrm{~g} \mathrm{~kg}^{-1}\right)$, this effect was not observed, possibly resulting from excess dietary $\mathrm{Ca}$.

These observed responses of BWG and FI are consistent with those observed for F:G. At the lowest Ca level, the highest MS level stimulated FI, thus decreasing F:G. The observed performance effects confirm the influence of $\mathrm{Ca}$ on $\mathrm{F}: \mathrm{G}$ via the birds' FI.

These results are supported by Bao et al. (2007), who observed better performance in the group of broilers whose diet contained moderate levels of organic mineral, close to those used in the present study and lower than those recommended by the NRC, (1994). Corroborating these results, Peric et al. (2007) and Nollet et al. (2008) found that supplementation with organic minerals souces at levels lower than those currently used with inorganics does not affect the performance of broiler chickens. Both studies also verified that $\mathrm{Ca}$ levels lower than 10 and $12 \mathrm{~g} \mathrm{~kg}^{-1}$ and greater than $8 \mathrm{~g} \mathrm{~kg}^{-1}$ yielded favorable performances in broiler chickens when used in combination with organic mineral sources. 
When evaluating the effect of increasing dietary Ca levels, Qian et al. (1997) and Alves et al. (2002) observed decreased consumption and weight gain as the level of this mineral in the feed increased. This reduction in consumption with increasing dietary Ca may be related to elevated ionic $\mathrm{Ca}$ in the blood, which inhibits the birds' appetite (Lobaugh et al., 1981). Reduced consumption results in lower nutrient availability and utilization, which Shafey et al. (1991) attributed to a decrease in nitrogen digestion. However, this lower nutrient utilization can be attributed to an increased intestinal microflora population, causing increasing irritation in the intestinal mucosa. In contrast, Salter (1973) reported an increase in mucosal thickness, which would impede effective intestinal absorption and diminish dietary transit.

The responses of bone tissue development was dependent on the dietary $\mathrm{Ca}$ level, with $\mathrm{Ca}$ and ash deposition being positively affected and $\mathrm{P}$ deposition negatively affected by higher Ca levels. These results are consistent with the fact that an intermediate Ca level $10 \mathrm{~g}$ $\mathrm{kg}^{-1}$ ) is currently recommended, following requirements suggested by Rostagno et al. (2011) that the Ca levels need to be $0.92 \mathrm{~g} \mathrm{~kg}^{-1}$ (one-to seven days old) and $0.84 \mathrm{~g}$ $\mathrm{kg}^{-1}$ (eight to 21d old), and support the higher Ca level $\left(12 \mathrm{~g} \mathrm{~kg}^{-1}\right)$ and impaired $\mathrm{P}$ deposition in the bird tibia.

High dietary Ca levels may impair the efficiency of phytase, which was used in all experimental diets in this study, and interfere with the absorption of $\mathrm{Ca}, \mathrm{P}, \mathrm{Zn}$ and $\mathrm{Mn}$. Very low Ca levels impair $\mathrm{P}$ absorption, consequently reducing the concentrations of these minerals in the tibia (Schoulten et al., 2002).

Shafey et al. (1991) found that a high Ca concentration (greater than $15.3 \mathrm{~g} \mathrm{~kg}^{-1}$ ) in the feed elevated the $\mathrm{pH}$ of the crop and ileum contents but did not affect the $\mathrm{pH}$ of the other segments of the chicken's gastrointestinal tract. This result suggests that the elevation of intestinal $\mathrm{pH}$ as a function of increasing dietary Ca levels reduces the soluble fraction of minerals and their availability for absorption. According to the NRC, (1994), the Ca requirement for one- to 21-day-old broilers is $1 \%$ for diets of 3,200 kcal kg-1. However, Karunajeewa (1976) concluded that $6 \mathrm{~g} \mathrm{~kg}^{-1} \mathrm{Ca}$ and $5.7 \mathrm{~g} \mathrm{~kg}^{-1}$ phosphorus are sufficient for adequate growth and bone formation when the minerals are present in highly available forms.

In the present study, the interaction between $\mathrm{Ca}$ and MS levels in tissue concentration suggests that although higher Ca levels may affect micromineral utilization, these effects may have been minimized by the use of organic mineral sources with high bioavailability. Consequently, this apparently increased the liver and breast Se and Mn concentrations without reducing the $\mathrm{Fe}$ and $\mathrm{Zn}$ concentrations. The organic mineral sources of Se and Mn effectively permitted the deposition of these minerals in the tissues. Notably, several studies using inorganic selenium salts have found no increase in the concentration of this mineral in the breast. This micromineral is of interest to the industry because pro- ducers are currently seeking to increase its concentration in human food and to advance the productive characteristics of broilers. Thus, Se supplementation is an important strategy to enrich the final product.

Bao et al. (2007) found that trace mineral concentrations $(\mathrm{Cu}, \mathrm{Fe}, \mathrm{Mn}$ and $\mathrm{Zn})$ in the livers of broilers fed a control diet without MS were higher than those in supplemented birds (three levels of organic minerals and one inorganic). Similar results have been attributed to a dilution effect as a result of rapid growth of adequate diets and slow growth in the control diet (Roth, 2003).

Ao et al. (2009) evaluated the effects of different forms of $\mathrm{Zn}$ and $\mathrm{Cu}$ on broiler performance and tissue mineral content and observed that liver $\mathrm{Cu}$ concentration was reduced by $\mathrm{Zn}$ supplementation. The $\mathrm{Zn}$ content in the duodenal mucosa increased with the addition of organic $\mathrm{Zn}$ in the diet, and the $\mathrm{Cu}$ content in the duodenal mucosa also increased with the addition of both organic $\mathrm{Zn}$ and $\mathrm{Cu}$.

Schoulten et al. (2002) found that increasing the Ca level decreased $\mathrm{Mn}$ absorption, while Sebastian et al. (1996) found no effect on the relative retention of $\mathrm{Mn}$ in one- to 21-week-old broiler chickens when dietary $\mathrm{Ca}$ was increased from 6 to $12.5 \mathrm{~g} \mathrm{~kg}^{-1}$.

$\mathrm{Li}$ et al. (2005) evaluated Mn bioavailability in diets with a high Ca level $\left(18.5 \mathrm{~g} \mathrm{~kg}^{-1}\right)$ and a normal Ca level $\left(11.7 \mathrm{~g} \mathrm{~kg}^{-1}\right)$ and found that organic Mn with moderate or strong chelation strength could partially or completely resist the antagonistic effect of increased dietary $\mathrm{Ca}$ during digestion and exhibited higher relative bioavailability than under normal dietary $\mathrm{Ca}$ conditions.

The organic sources in higher levels of MS 10.82 and $0.92 \mathrm{~g} \mathrm{~kg}^{-1}$ ) were responsible for an increase in the mineral concentration of $\mathrm{Zn}, \mathrm{Mn}$ and Se in tissues. An MS interaction with $\mathrm{Ca}$ influenced $\mathrm{Fe}, \mathrm{Cu}$ and $\mathrm{Se}$. These levels are lower than the current levels practiced for better growth or a better feed-to-gain ratio. These results show the importance of using the sources and levels effectivily to permit higher tissue concentration and are perharps reflected in health or meat quality. The impact of $\mathrm{Ca}$ levels needs to be observed in the production system because low levels impaired better growth performance and higher levels interact more with the concentration of microminerals in tissues.

The observed $\mathrm{Cu}$ and $\mathrm{Fe}$ micromineral concentrations in the litter reflected only the increase in MS, showing higher concentrations with increasing MS in the diet. The interaction between Ca and MS levels confirmed that Ca can interfere with micromineral absorption and, consequently, excretion. Excretion is reduced when the Ca level recommended by Rostagno et al. (2011), i.e., $10 \mathrm{~g} \mathrm{~kg}^{-1}$, is used, as shown by the results for excreted Se, Mn and $\mathrm{Zn}$.

Bao et al. (2007) also detected a linear increase in $\mathrm{Cu}, \mathrm{Mn}, \mathrm{Zn}$ and $\mathrm{Fe}$ excretion with increasing consumption of these microminerals. Thus, birds that were supplemented with $0.82 \mathrm{~g} \mathrm{~kg}^{-1} \mathrm{MS}$ and $10 \mathrm{~g} \mathrm{~kg}^{-1} \mathrm{Ca}$ and 
assured the best performance had lower excretion than those in treatments with a higher MS level. Bao et al. (2010) utilized microminerals from organic sources and evaluated the interaction between them, finding in one experiment that adding $\mathrm{Cu}, \mathrm{Fe}, \mathrm{Mn}$ and $\mathrm{Zn}$ in combination not only affected the concentrations of the trace minerals but also influenced $\mathrm{Ca}$ and $\mathrm{P}$ excretion. These authors also showed that Mn supplementation alone increased only Mn excretion and not the excretion of the other minerals. Compared to Mn supplementation, combined supplementation with $\mathrm{Zn}, \mathrm{Mn}, \mathrm{Cu}$ and Fe had no additional effect on $\mathrm{Mn}$ excretion but showed decreased $\mathrm{Ca}$ excretion and increased $\mathrm{Cu}$ and $\mathrm{Fe}$ excretion.

Using $50 \%$ of the $\mathrm{NRC}$, (1994) recommendation for the microminerals $\mathrm{Zn}, \mathrm{Mn}$ and $\mathrm{Cu}$ in organic form and 10.7 or $9 \mathrm{~g} \mathrm{~kg}^{-1} \mathrm{Ca}$ in broiler diets, El-Husseiny et al. (2012) found improved performance and carcass yield and lower excretion of these minerals compared to birds whose diet contained $100 \%$ of the recommendation in inorganic form. Manangi et al. (2012) compared low $\mathrm{Zn}, \mathrm{Cu}$ and $\mathrm{Mn}$ levels from organic sources to the industry-standard supplementation levels of the same minerals from inorganic sources. These authors found that the concentration of these microminerals was reduced in the litter of birds supplemented with $\mathrm{Zn}, \mathrm{Cu}$ and $\mathrm{Mn}$ from organic sources by 40,74 and 35 $\%$, respectively. In contrast, there was no difference in $\mathrm{Zn}, \mathrm{Cu}, \mathrm{Ca}$ and $\mathrm{P}$ concentrations in the tibiae of animals that received high dietary supplementation levels from inorganic sources.

The present study demonstrates that micromineral supplementation from organic sources decreases antagonistic interactions with macromineral $\mathrm{Ca}$ and reduces binding with nutrients and non-nutritive components of the digesta resulting in less negative interaction in absorption and, consequently, better utilization of these minerals by poultry, favouring adequate tissue deposition (breast and liver) and lower excretion.

\section{Conclusion}

The Ca level of $10 \mathrm{~g} \mathrm{~kg}^{-1}$ combined with an MS level of $0.82 \mathrm{~g} \mathrm{~kg}^{-1}$ results in greater weight gain, higher deposition of the macrominerals $\mathrm{Ca}$ and $\mathrm{P}$ in bone tissue and of the microminerals $\mathrm{Mn}, \mathrm{Zn}, \mathrm{Fe}, \mathrm{Cu}$ and $\mathrm{Se}$ in the liver and breast and lower excretion of these microminerals in the litter.

\section{Acknowledgments}

The authors would like to thank the Coordenação de Aperfeiçoamento de Pessoal de Nível Superior (CAPES), Conselho Nacional de Desenvolvimento Científico e Tecnológico (CNPq), Fundação de Amparo à Pesquisa do Estado de Minas Gerais (FAPEMIG), Institutos Nacionais de Ciência e Tecnologia (INCT) and Universidade Federal de Viçosa for important financial support.

\section{Authors' Contributions}

Conceptualization: Faria, B.D.; Hannas, M.I.; Rostagno, H.S.; Albino, L.F.T.; Ferreira, A.H.N. Data acquisition: Faria, B.D.; Silva, L.M. Data analysis: Faria, B.D.; Hannas, M.I.; Rostagno, H.S.; Albino, L.F.T. Design of methodology: Faria, B.D.; Hannas, M.I.; Rostagno, H.S.; Albino, L.F.T. Software development: Faria, B.D.; Ribeiro Junior, V. Writing editing: Faria, B.D.; Hannas, M.I.; Ribeiro Junior, V.

\section{References}

Alves, E.L.; Teixeira, A.S.; Bertechini, A.G.; Rodrigues, P.B.; Oliveira, A.I.G. 2002. Effects of the level of calcium in two sources on broiler chicken performance $=$ Efeito dos níveis de cálcio em duas fontes sobre o desempenho de frangos de corte. Ciência e Agrotecnologia 26: 1305-1312 (in Portuguese).

Ao, T.; Pierce, J.L.; Power, R.; Pescatore, A.J.; Cantor, A.H.; Dawson, K.A.; Ford, M.J. 2009. Effects of feeding different forms of zinc and copper on the performance and tissue mineral content of chicks. Poultry Science 88: 2171-2175.

Association of Official Agricultural Chemists [AOAC]. 1984. Official Methods of Analysis of the AOAC. 14ed. AOAC, Rockville, MD, USA.

Association of Official Agricultural Chemists [AOAC]. 2000. Official Methods of Analysis of the AOAC. 17ed. AOAC, Rockville, MD, USA.

Bao, Y.M.; Choct, M.; Iji, P.A.; Bruerton, K. 2007. Effect of organically complexed copper, iron, manganese, and zinc on broiler performance, mineral excretion, and accumulation in tissues. Journal of Applied Poultry Research 16: 448-455.

Bao, Y.M.; Choct, M.; Iji, P.A.; Bruerton, K. 2010 Trace mineral interactions in broiler chicken diets. British Poultry Science 51: 109-117.

Dibner, J.J.; Richards, J.D.; Kitchell, M.L.; Quiroz, M.A. 2007 Metabolic challenges and early bone development. Journal of Applied Poultry Research 16: 126-137.

Dieck, H.T.; Doring, F.; Roth, H.P.; Daniel, H. 2003. Changes in rat hepatic gene expression in response to zinc deficiency as assessed by DNA arrays. Journal of Nutrition 133: 1004-1010.

El-Husseiny, O.M.; Hashish, S.M.; Ali, R.A.; Arafa, S.A.; El-Samee, L.D.A.; Olemy, A.A. 2012. Effects of feeding organic zinc, manganese and copper on broiler growth, carcass characteristics, bone quality and mineral content in bone, liver and excreta. International Journal of Poultry Science 11: 368-377.

Fiske, C.H.; Subbarow, Y. 1925. The colorimetric determination of phosphorus. Journal of Biological Chemistry 66: 375-400.

Karunajeewa, H. 1976. Effect of some feed additives on the performance of broiler chicks fed diets containing high levels of meat and bone meal. Australian Journal of Experimental Agriculture and Animal Husbandry 16: 685-690.

Li, S.F.; Luo, X.G.; Lu, L.; Crenshaw, T.D.; Bu, Y.Q.; Liu, B.; Kuang, X.; Shao, G.Z.; Yu, S.X. 2005. Bioavailability of inorganic manganese sources in broilers fed high dietary calcium. Animal Feed Science and Technology 123-124: 703-715.

Lobaugh, B.; Joshua, I.G.; Mueller, W.J. 1981. Regulation of calcium appetite in broiler chickens. Journal of Nutrition 111: 298-306. 
Manangi, M.; Vazquez-Anon, M.; Richards, J.; Carter, S.; Buresh, R.; Christensen, K. 2012. Impact of feeding lower levels of chelated trace minerals versus industry levels of inorganic trace minerals on broiler performance, yield, footpad health, and litter mineral concentration. Journal of Applied Poultry Research 21: 881-890.

National Research Council [NRC]. 1994. Nutrient Requirements of Poultry. National Academies Press, Washington, DC, USA.

Nollet, L.; Huyghebaert, G.; Spring, P. 2008. Effect of different levels of dietary organic (Bioplex) trace minerals on live performance of broiler chickens by growth phases. Journal of Applied Poultry Research 17: 109-115.

Peric, L.; Nollet, L.; Milosevic, N.; Zikic, D. 2007. Effect of bioplex and sel-plex substituting inorganic trace mineral sources on performance of broilers. Archiv fur Geflugelkunde 71: 122-129.

Qian, H.; Kornegay, E.T.; Denbow, D.M. 1997. Utilization of phytate phosphorus and calcium as influenced by microbial phytase, cholecalciferol, and the calcium: total phosphorus ratio in broiler diets. Poultry Science 76: 37-46.

Rostagno, H.S.; Albino, L.F.T.; Donzele, J.L.; Gomes, P.C.; Oliveira, R.F.; Lopes, D.C.; Ferreira, A.S.; Barreto, S.L.T.; Euclides, R.F. 2011. Brazilian Tables for Poultry and Swine: Composition of Feedstuffs and Nutritional Requirements. 3ed. Universidade Federal de Viçosa, Viçosa, MG, Brazil.

Roth, H.P. 2003. Development of alimentary zinc deficiency in growing rats is retarded at low dietary protein levels. Journal of Nutrition 133: 2294-2301.
Salter, D. 1973. The influence of gut micro-organisms on utilization of dietary protein. Proceedings of the Nutrition Society 32: 65-71.

Schoulten, N.A.; Teixeira, A.S.; Bertechini, A.G.; Freitas, R.; Conte, A.J.; Silva, H.O. 2002. Effect of calcium levels on minerals absorption in initial diets to broilers supplemented with phytase. Ciência e Agrotecnologia 26: 1313-1321 (in Portuguese, with abstract in English).

Sebastian, S.; Touchburn, S.P.; Chavez, E.R.; Lague, P.C. 1996. Efficacy of supplemental microbial phytase at different dietary calcium levels on growth performance and mineral utilization of broiler chickens. Poultry Science 75: 1516-1523.

Shafey, T.M.; Mcdonald, M.W.; Dingle, J.G. 1991. Effects of dietary calcium and available phosphorus concentration on digesta $\mathrm{pH}$ and on the availability of calcium, iron, magnesium and zinc from the intestinal contents of meat chickens. British Poultry Science 32: 185-194.

Smith, O.; Kabaija, E. 1985. Effect of high dietary calcium and wide calcium/phosphorus ratios in broiler diets. Poultry Science 64: 1713-1720.

Waldroup, P. 1996. Bioassays remain necessary to estimate phosphorus, calcium bioavailability. Feedstuffs 68: 13-20.

Wise, A. 1983. Dietary factors determining the biological activities of phytate. Nutrition Abstracts and Reviews 53: 791-806. 